\title{
THE RELATIONSIP BETWEEN ENTREPRENEUR'S LEVEL OF PERCEIVED BUSINESS-RELATED FEAR AND BUSINESS PERFORMANCE
}

\author{
*Nevin Deniz \\ *Illknur Taştan Boz \\ **Öznur Gülen Ertosun \\ *Marmara University \\ **Gebze Institute of Technology
}

\begin{abstract}
There is increasing awareness about fear's effect on the quality of human performance in the workplace (Briksin, 1996; Garcia- Zamor, 2003; Gerst, 1995). In the light of this proposition, improving the entrepreneur's capability to manage his or her own fears may have a high probability of increasing business performance. An expected outcome of this study is that if fear affects workplace behavior and play a significant role in workplace performance, then it would be important for entrepreneurs to understand how fear can limit their business success. Fear of the entrepreneur's results for business performance has very few studied empirically (Collins, 2007). This study adds to the body of knowledge by exploring the fears of entrepreneurs and the relationship of fear and business performance. The result of study is valuable for both academia and practitioners.

The article proceeds in the following manner. First, we briefly review the literature regarding fear in the workplace, entrepreneurship and results for business performance. We develop hypotheses concerning the relationship between entrepreneur's the level of perceived business-related fear on business performance. Next, we test our hypotheses using data from 255 enterprises owner from various scale firms (micro-small-medium sized and corporate firms) in Istanbul. In this study various valuable demographic description which is supported by literature is done for the participated enterprise owners. And findings of regression analyzes indicated that as a fear dimension "fear of legal issues" is a supported dimension with the association with both financial and innovative performance.
\end{abstract}

Keywords: Entrepreneurship; Fear; Business Performance

\section{INTRODUCTION}

In the literature there are numeric factors that effect business performance of entrepreneurship are investigated for a long time and most of them are well-known and can be accepted as traditional factors. For instance; being burn global (Oviatt and McDougall defined born global companies that "from inception, seek to derive significant competitive advantage from the use of the resources and sales of outputs to multiple countries" (1994, p. 49) has been found in relation with performance (Aspelund \& Moen, 2005; Knight \& Cavusgil, 2005; Gleason, Madura et al., 2006). In addition to this, Harting (2005), along with several others, suggests that the knowledge and experience of the business owner are key human performance factors that have a positive effect on increasing the business success (Chowdhury \& Lang, 1993; Cochran, 1981; Gaskill, Van Auken \& Manning, 1993; Haswell \& Holmes, 1989; Kennedy, Loutzenhiser \& Chaney, 1979; Otterbourg, 1989; Worthington, 1984). As another well-known predictor is that if a company goes on after first five years, then it is a successful company. And beside these, the external and are largely economic factors are effective on business performance; such as economy, capital markets, actions, strategies adopted by competitors, changes in government policies and regulations (i.e., Shane, 2003). Apart from traditional factors that influence the success of new ventures are the actions of entrepreneurs; the decisions they make, the strategies they develop, the style of leadership that is cognitive processes play a key role in all of these activities.

Entrepreneurs' both cognitive and emotional process is just new and few studied. It is recently suggested that a cognitive perspective may provide important insights into key aspects of the 
entrepreneurial process. Specifically, it is proposed that this perspective can help the field of entrepreneurship to answer three basic questions it has long addressed: (1) Why do some persons but not others choose to become entrepreneurs? (2) Why do some persons but not others recognize opportunities for new products or services that can be profitably exploited? (3) Why are some entrepreneurs so much more successful than others? It is suggested that a cognitive perspective can prove beneficial both to researchers wishing to understand entrepreneurship as a process and to practitioners hoping to assist entrepreneurs in their efforts to create successful new ventures. (Baron, 2004)

However, the theoretical and empirical research has been inconsistent and limited (Brundin et al., 2008; Cardon et al., 2009; Corbett, 2007; Corbett and Hmieleski, 2007) entrepreneurship research has only recently begun to focus more on the effect of cognitions and emotions. The interaction between emotions and cognition are reciprocal in nature so that, feelings shape thought and thought shapes feelings (i.e. Isen and Baron, 1991). Following current appraisal theories, cognitions (opinion, belief and judgment) are believed to play a central role in the formation of emotions (i.e. Lazarus, 1991; Roseman, 2001; Barsade and Gibson, 2007). Thereby, emotions are defined as affective experiences, including such things as joy, surprise, anger, fear and hope. By defining entrepreneurship as a cognitive process (i.e. Shane and Venkataraman, 2000; Shane, 2003), scholars have analyzed cognitive biases that distinguish entrepreneurs from other groups of people (Baron, 1998; Sarasvathy et al., 1998).

According to related researches once fear or any other emotion is elicited, can influence the cognitive processes, such as decision-making, even when the emotion does not stem from the objects, persons, or events being evaluated (Forgas, 2000; Gangemi and Mancini, 2007; Foo, 2010). As Hareli, Shomrat and Biger (2005) state emotion as a related factor on explaining failures both in social psychology and organizational research; according to Runyan (2005) fear is a powerful emotion that typically contributes to the inability to make progress toward goals. In addition to this Burn de Pontet (2004) says that fear in terms of feeling threatened by potential failure, anxiety, self-doubt and rejection is one of reason for business failure. The fear factor then leads to avoidance behavior and inaction and without action that causes failure. Grichnik et al. (2010) in their study investigated emotional experiences effect on entrepreneurial behavior; the results show that positive and negative emotions significantly decrease the preferences of entrepreneurs to allocate additional time and resources to the exploitation of new opportunities. Spesifically Colins (2007) studied the entrepreneurs' fear factor on performance and found a significant association between the variables. Based on such suggestions this study is designed to determine the fear factor on overall business performance.

\section{LITERATURE REVIEW}

\section{Entrepreneurship:}

Entrepreneurship is the practice of starting new organizations or revitalizing mature organizations, particularly new businesses generally in response to identified opportunities. Entrepreneurship is often a difficult undertaking (Shahhosseini, 2011). Howorth, Tempest, Coupland (2005) and Jack, Anderson (1999) state that a solid definition of entrepreneurship or an entrepreneur continues to generate debate and a single definition has not yet been embraced across the various paradigms. This study uses the common working definition put forth by Jones (2002) that an entrepreneur is an individual who establishes and manages a business for the principles of profit and growth. Entrepreneurs known as taking at least moderator level of risks such as: economic, social, carrier, psychological and health (Naktiyok, 2004).

Entrepreneurship is a dominant factor in the economy; researchers have examined a number of factors that may explain entrepreneurial activity, though a good deal of recent research has tended to focus on the characteristics of the business and industry environment or the characteristics of the entrepreneurial opportunity itself (Kaufman \& Dant, 1998). Beside this, corporate ecosystem and entrepreneurial substructure (Börü, 2003, p.13) that is legal issues are important detrimant on entrepreneurship (Robson, 2009, p.444).

Our understanding of entrepreneurship will not be complete unless we understand the motivation of the individuals involved (Venkataraman, 1997). Recent research suggests that motivational traits and creativity are important factors in entrepreneurial activity and success (Baum, Locke \& Smith, 2000; 
Stewart \& Roth, 2001). Research on the motivational traits of entrepreneurs seems especially promising for helping to identify those individuals that might be best suited for identifying and exploiting entrepreneurial opportunities in the market place (Shane \& Venkata Raman, 2000). McClelland's theory that achievement motivation is significantly related to both occupational choice and performance in an entrepreneurial role (Farzaneh et al. 2010). Baron has defined motivational factors of entrepreneurship as self-efficacy positive affectivity, specific skills and competencies, and situation-specific motivation (Baron, 2004). Despite the potential importance of individual characteristics, there are still many unanswered questions regarding the role that motivation and personal characteristics have on entrepreneurial activity (Shane \& Venkataraman, 2000, Farzaneh et al. 2010) And also personal initiative is one of the major key to success on entrepreneurship; entrepreneurs with high personal initiative will naturally overcome the disadvantages or weaknesses in them with their self-starting and proactive attitude (Rose et al., 2006,p.74).

As a leading factor family is also effective on being entrepreneur; Families' ways of behavior especially patriarchal families are strongly effective on choices and personal development (Jahoda, 1993). Liberal attitudes of parents motivates enterpreneur characteristics of the child (Erdoğan 1994). And generally if entrepreneurship is parental, this motivates being entrepeneur; and paralel to this worker's and officer's children are influenced from father's occupations as well (Bridge, 1998, p.54) . Moreover, in some studies their parents own business found to have a positive relationship with their success. (Rose et al.,2006, p.74)

Demografic factors such as higher educational level, working experience (Rose et al., 2006), being the first child of family, being male, age, marriage, income of familiy and socio-economic statu are investigated and found with higher probability as detrimants of prefering being entrepreneur (Coulter,2001, p.16-17).

\section{Fear in the Workplace:}

Fear can be defined as a high level of emotional arousal caused by perceiving a significant and personally relevant threat. Fear motivates both protective and maladaptive action, depending on the circumstances (Witte, 1999, Thongsukmag, 2003, p25). Additionally fear is an unpleasant physical and emotional response to a detected threat or danger; or a concern or anxiety about an undetected consequence that threatens to bring bad news or bad results (Dobson, 2006; Oxford, 2006). As Goldsmith (2002, p.39) states, fear effects productivity, communication, ability to create and emotional well-being. Gibb claims that individual characteristics such as motivation, consciousness, perception, emotion, cognition, action and synergy are impacted negatively when high levels of fear are evident. For instance, when fear is felt strongly, an individual may be unable to focus affectively when examine a problem due to an impaired perception of the task at hand (Collins, 2007). "Prolonged fear can possibly cause "maladaptive behavioral psychological and somatic responses to stressors" which is labeled as "strain" (Wofford, Goodwin, \& Daly, 1999, p.688).

For nearly a century, countless studies of fear have been conducted and revisited comprehensively across a wide range of disciplines; such as psychology (LeDoux 1990, Lang, Davis \& Ohman, 2000, Witte, 1992; Forbe \& Roger, 1999), political field (Ahmed, 2002), architecture (Ellin, 1997), adult learning (Daloz, 1988) and sociology (Rachman, 1974, 1978, 1980, Thongsukmag, 2003, p26).

Fear in the workplace is defined as feeling threatened by possible repercussions as a result of speaking up about work-related concerns. These feelings of threat may come from four sources: actual experience, stories about others' experiences, assumptions and interpretations of others' behavior, and culturally based stereotypes about those with supervisory power (Ryan, 1991, p. 21). The notion of fear is an integral part of the workplace and can be a valuable motivating tool, driving employees to learn new skills, and perform at higher levels. According to Ashkanasy and Nicholson (2003) fear in the workplace can be defined as generalized apprehension at work. While fear can be utilized as a positive device, and cannot be eliminated from human emotion (Leon, 2002), under certain conditions fear and hostility can be an overriding negative force within an organization. From a psychological perspective fear is considered a negative emotion, because when experienced the effect is often distressing and tends to have an adverse impact on the individual (Strongman, 1996). It is also however, a normal emotion and is an appropriate response to a known threat of danger. Fear has multiple symptoms, including fatigue, depression, restlessness, aggression, loss of appetite, and insomnia (Doctor \& Kahn, 1989). In other words, fear has the potential to induce certain stress responses or behaviors, such as flight or fight, suppression, or helplessness. There is indication in the 
literature that negative interpersonal behaviors at work can affect various organizational and attitudinal variables, namely higher turnover and job dissatisfaction (Cox, 1987).

While some people have a difficult time dealing with work-related fears, others do not. There are many factors that contribute to discrepancies in coping strategies among individuals such as personality, job status, marital status, level of education, and years of experiences (Kirkcaldy \& Furnham, 1999; McCrae and Costa, 1986; Fleishman, 1984). Sex is also one of those factors that effect how individuals experience as well as cope with work-related fears (Siegler \& George, 1983; Billings \& Moos, 1984). Several studies have placed emphasis on the role of sex on work-stress or coping strategies (Greenglass, 1995; Spielberger\& Reheiser, 1995; Trocki \& Orioli, 1994, Kohlmann, 1993b). Given the premise that sex plays a considerable role during a coping period (Thongsukmag, 2003, p11).

\section{Fears of Enterprise Owners and the Relationship with Performance:}

Lipper (1989) looks at several positive aspects of fear and how fear can be useful in the workplace. He believes that an entrepreneur needs to understand the types of fear their business competitors, whom they partner with and against, are experiencing because they will reflect the way they do business. Beside competitors their own fear factors are effective on their attitudes, so knowledge about fear factors is important for business owners.

The fear of losing key employees, the fear of product obsolescence is a goad to continuing research and development (Lipper, 1989, p.191) accordingly; they tend to focus on eradicating the discomfort caused by fear of monitoring as opposed to accomplishing the desired positive productivity (Hochschild, 1983). Correspondingly, Scarnati (1998) exemplifies how the extreme fear of litigation paralyzed the 1970s Xerox Corporation, which was once considered a vigorous and innovative company in making effective decisions during its legal battles. He further narrates that because of the fear of receiving a lawsuit, every step of the decision-making process has unnecessarily employed the services of lawyers. As a result, too much time and effort is inevitably consumed for executing business decisions that are trivial or potentially profitable (Thongsukmag, 2003, p42).

As explained in above, entrepreneurs' the most deterministic property is taking risk and entrepreneurship is affected by the wider population's view on risk, since entrepreneurs rely on the participation of stakeholders like employees, investors, suppliers and others. Risk is in the heart of fear of failure for the entrepreneurship. The GEM global report (2009) has investigated fear of failure among different cultures and the institutional environment such as employment potection affects the difference on fear of failure perception among countries. As a result highest fears of failure rates of entrepreneurship have the lowest intentions to start businesses. Yorton (2005) and Tuvin (1995) discussed the high cost of fear in the workplace, which includes stifled creativity, diminished innovation, muted candid interpersonal relationships, and reduced fun on the job. Fear of organizational change, fear of a change in the marketplace and its potential affect on business and commerce, fear from a growing distrust of large institutions or the government (Yorton, 2005). The ability to take risk is clearly an entrepreneurial trait, yet entrepreneurs can be stuck by the fear of taking chances because the answers 'when and how' are to take a risk are unknowns (Mogharabi, 2005).

Not having enough resources and information to be successful has been shown to be a workplace fear in literature. Fear of not having enough resources relates to not being able to hire the right people, have the right equipment, space for work, or money to pay creditors. It has also been described as not having enough support from employees, family, friends, mentors, vendors, or community agencies (Cook, 2005; Ryan \& Oestreich, 1998).

Especially the small business owner may be worried about disappointing the employees, investors, stockholders or losing the respect of family, friends, customers, suppliers or others can be destructive for them. As well as fears of losing power or prestige, fear of having one's reputation damaged, or fear of losing a valuable relationship (Cook, 2005; Ryan \& Oestreiech, 1998) is found to be important dimensions of fear for entrepreneur. Fear of failure is the most common fear that slows down progress toward goals (Moules, 2005, Pieper, 2003; Schlossberg, 1990; Staley, 1972; White, 2004). Dejitthirat (2004) states that fear of failure and avoidance of personal goals is common across all cultures.

Lindeman's (2002) study, on the role of stress and negative emotions related to a career crisis, 
identified personal illness and worries about family/relatives as a major factor that can affect small business owners. Because the solo, micro, and small business owners are one of the main, and often the only, contributors to the business, an illness that slows the owner down, affects both the quality of life and profits (Frese, Brantjes, \& Hoorn, 2002). Danger such as violence in the workplace and having no one to succeed or replce him and conflict with others found as an effective stres factor especially for small business owners Alliance (2001).

As Loehr and Schwartz (2002) stated: "Just as positive emotions ignite the energy that drives high performance, negative emotions - frustration, impatience, anger, fear, resentment, and sadness - drain energy. Over time, these feelings can be literally toxic, elevating heart rate and blood pressure, increasing muscle tension, constricting vision, and ultimately crippling performance" (p. 78). Recently as several researchers suggest, the capabilities of entrepreneurs to manage their fear are a major contributing factor to business performance (Blanke, 2004; Buck, 2004; Helms, 2003; Stern, 2004; Tebbutt, 2005; Thongsukmag, 2003; Weinberg, 2004; White, 2004). Cooper suggests that "at highly competitive managerial levels ... it is likely that problem-solving will be inhibited for fear of appearing weak" (Cooper, 1981, p. 281). English \& Sutton (2001) convey the notion that, despite the positive knowledge, skills, and experience of those managers who work in a rapidly changing work environment, those qualities alone will not be sufficient to perform their job effectively if they are unable to cope with their own fears. Though having the ability to perform at an acceptable level is admirable, they express, "an individual's ability to work with courage and face up to their own fears is central to their effectiveness at work" (p.211). Hence, a manager's ability to perform effectively is undeniably influenced by how well the coping strategies adopted aid individuals in handling those fears that are present (Thongsukmag, 2003, p11). After all the main hypothesis of the study is in the following:

H1: There is relationship between entrepreneur's level of perceived business-related fear and business performance.

\section{Figure 1. Conceptual Model}

$$
\begin{gathered}
\text { Entrepreneur's } \\
\text { demographic } \\
\text { properties }
\end{gathered}
$$

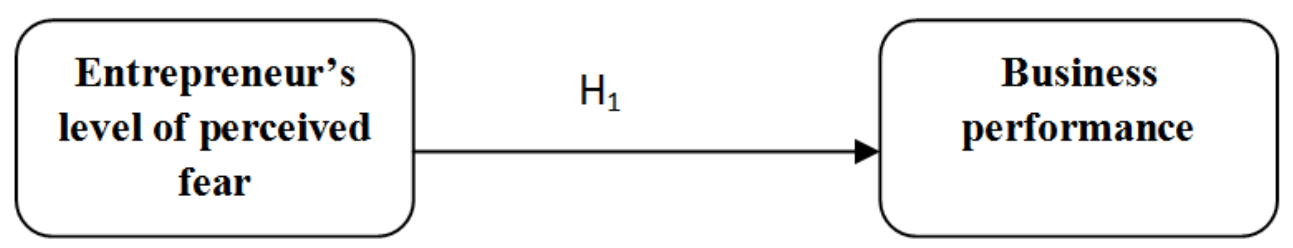

\section{RESEARCH DESIGN}

\section{Data Collection}

Scope, hypotheses, research model, scales used in the research and sample is explained in this section. After theoretical background is given, in order to test the research model statistical analyses have been done. Data needed for field search has been collected through face-to-face questionnaire technique with enterprise owners of various size manufacturing and service sector companies $(34,7 \%$ of them service and 65,3\% manufacturing). According to KOSGEB criteria, 21,2 \% of companies are micro (less than 10 employee), 27,9\% from the companies are small-sized (employee number is between 11 -50 ), 35,6 \% medium sized (employee number is between 51-150) and 15,3\% of them are big companies (more than 150 employee). The entrepreneurs participated to the study were randomly selected and total number of valid questionnaires were 255. Gathered data have been analyzed in SPSS software with the help of the correlation and regression, t-test and anova analysis. 


\section{Demographic Properties of the Entrepreneurs}

Success Factors: We asked if they are "born global" companies which means in the first years (especially first five year) the company has export trade, 33,8\% of them was born global and rest of them not. And as another expression 38,7\% from the enterprises still has export trade. This is an important criterion for performance and in the related literature; Knight and Cavusgil (2005) find that the earlier the firm internationalizes, the better its performance in foreign markets. A few studies have examined long run performance of born global firms comparing to others, although the results have been mixed, generally significant associations were found (Aspelund \& Moen, 2005; Knight \& Cavusgil, 2005; Gleason, Madura et al., 2006).

Because the first five year is critical (i.e. Cooper et al., 1989) for especially small sized enterprises so we classified the period of companies according to this information; in the sample; $29 \%$ of the enterprises are in the first five year; $28,5 \%$ of them are on the second critical period (between 6 and 10 year), rest of them are in operate more than 10 years $(42,5 \%)$. Industry specific experiences are asked because it can be effective on firm performance as well (Harting, 2005); 33,8\% of the enterprise owners has experience less than 10 year and 66,2 of them has more than 10 year experience in the sector.

Beside this expressions and performance scale we asked as a yes-no question if they are satisfied with their firms performance; most of them $(81,4 \%)$ said yes and rest of them said no.

Above the information about literature related success factors, our sample contains mostly experienced and successful or at leased satisfied with the success level of their companies.

Personal Factors: Various specific questions are asked to entrepreneurs in the light of the related literature; Enterprise owners' $81,8 \%$ established the company and for rest of them the company is parental $(18,3 \%)$. Nearly half of them established another company $(45 \%)$ and for rest of them this is the first company they owned.

In literature; being single or plural child, being first or last child; entrepreneurs' father model and also father' occupation are investigated and in the literature some suggestions are exist about the relationship being entrepreneur and this variables. So we asked and findings indicates that $5,9 \%$ of the entrepreneurs are single child and $94,1 \%$ of them are plural children and literature suggest that being first child is effective on this selection (Coulter,2001) for our sample there is no difference among being first, last or middle child; scores are similar (36\%: first child; $29,7 \%$ : last child and $34,2 \%$ others). Father's attitudes as being strict or liberal are found to be effective on being entrepreneur in the literature (Jahoda, 1993, Erdoğan 1994) however results of this study refers no such a distinction on being entrepreneur (31,5\% expressed that their father are strict, 32,4\% defined their father as a liberal and rest of them didn't made such a differentiation). Father's occupation are divided 4 dimension and agriculture as a specific occupation were surprisingly has a great number $(11,3 \%)$ and this may because of participants' age level (38,5\% of participants' age were above 45$)$. White collar workers were $25,8 \%$ of them and blue collar workers were $18,1 \%$. Almost half of the enterprise owners' fathers also were an enterprise (44,8\%). This is a supported finding in literature (Bridge, 1998).

In literature 8 reasons is classified to answer the question that "for you, what is the most powerful motivator for being an entrepreneur?"Mostly $(49,1 \%)$ said that they "want to be an employer"; the other six dimension is selected in similar scores (earning much money, using abilities freely, not having better job to do, having family company, taking risk, providing employ opportunity to others) and the least selected option was "flexitime" (0,9\%). Benzing et al., (2009, p.67), Kutanis \& Alpaslan (2006, p.146), Kutanis \& Hanc1 (2004, p. 459) and Karateke (2006, p.57) used the same dimensions in order to find motivator factors of entrepreneurs and parallel to our findings "want to be an employer" especially for men is one of the most strong motivator .

\section{Measures}

The constructs in our study are developed by using measurement scales adopted from prior studies. Fear of entrepreneur scale constructs are measured using five-point likert scales from "not at all fearful" to "very much fearful". Items for measuring entrepreneur's the level of perceived businessrelated fear are adopted to workplace by Collins (2007) from the scale used a combination of the fear cluster titles from Burnham, Gullone (1997) and Wolpe, Lang's (as cited by Farmilant, 1995) 1969 
fear survey schedules. The five clusters of fear that were examined were work/social stress, failure, the unknown, death/danger, and not having enough (resources or skills). And it is adapted to Turkish with a pilot analysis by the researchers of this study and from 25 items, 3 items are removed after exploratory factor analysis. Business performance scale which is adopted from Swamidas, Newell, (1987), Vickery et al., (1993, 1997), Rosenzweig et al., (2003) is a subjective and general performance measure. The performance scale is translated to Turkish by Eren and Zehir (2006). Performance scale is a subjective scale, because enterprise owners are reluctant to give information about numeric data. This is a widely used method in business literature and previous researches supported this as a valid and reliable method (Powell and Dent- Micallef, 1997; p. 388; Jayaram et al., 1999; p. 1023). The performance scale is also a five-point likert scale from "very low when comparing to industrial average" to "very high when comparing to industrial average". And demographic properties are prepared by researchers in the light of related literature.

\section{DATA ANALYSIS AND HYPOTHESES TEST RESULTS}

We used SPSS software 18.0 for the evaluation of our data. Factor analysis is used for the validity and cronbach alpha scale is used to estimate the reliability of the scales. Correlation and regression analysis were conducted to analyze the hypotheses of the study.

\section{Factor Analysis}

According to anti-image table values; all variables found higher than 0.50 ( $r>0.30)$, so all items took place in the factor analysis. Factor analysis with principal component by varimax rotation, that was performed to find out the factor structure, all dependent and independent variables are analyzed concurrent. Because some items were below 0.50 or having collinearity with more than one factor, and some factors contain one item it was continued to perform factor analyzing by removing the items one by one till the ideal table. And totally 6 items removed, rest of the items naturally revealed 7 factors. KMO $(0,779)$ and significance value $(\mathrm{p}=0.00)$ shows that our sample is suitable for the hypothesis analyzes.

Originally fear of entrepreneur scale composed of five dimensions as well, but some dimensions after some items removed differently named by this study's researchers. Fear of work/social stress and fear of unknown dimensions are named as original. But rested questions are named as fear of nonmonetary support, fear of uncertainty and fear of legal issues. This is a new questionnaire and Collins developed, used in his study so there is no study in the literature if the dimensions are supported or not by different samples, so this is our suggestion.

The other scale is developed by Eren and Zehir (2006) from various performance scales and in original composed of one dimension. However in this study the scale composed of 2 dimensions; when we look at the content; first dimension is about financial performance and the second is about innovative ability of firms. So dimensions are named as financial and innovative performance. 


\section{Table 1: Factor Loadings of the independendent variables: Fear of Entrepreneurs Scale Dimensions}

\begin{tabular}{|c|c|c|c|c|c|}
\hline $\begin{array}{l}\text { KMO: ,779 } \\
\text { Explained total variance: } \% 61,755\end{array}$ & $\begin{array}{l}\text { Fear of work/ } \\
\text { social stres } \\
\text { (\% var.9,725) }\end{array}$ & $\begin{array}{l}\text { Fear of } \\
\text { unknow } \\
\text { n } \\
(\% \text { var. } \\
8,747)\end{array}$ & $\begin{array}{l}\text { Fear of not } \\
\text { having non- } \\
\text { monetary } \\
\text { support } \\
\text { (\% var.8,631) }\end{array}$ & $\begin{array}{l}\text { Fear of } \\
\text { uncertani } \\
\text { ty } \\
\text { (var.8,104 } \\
\text { ) }\end{array}$ & $\begin{array}{l}\text { Fear of legal } \\
\text { issues } \\
(\% \text { var. } 7,333)\end{array}$ \\
\hline Losing the respect of my customers &, 847 & & & & \\
\hline Having my reputation smeared &, 817 & & & & \\
\hline Losing the love and respect of my family or friends & ,624 & & & & \\
\hline Being misunderstood & ,612 & & & & \\
\hline Employee/ partner/ executive fraud & &, 801 & & & \\
\hline Natural disasters & & ,759 & & & \\
\hline Not having enough time & & & ,704 & & \\
\hline Not having enough skills & & & ,670 & & \\
\hline No one to succeed or replace me & & & ,601 & & \\
\hline $\begin{array}{l}\text { Making mistakes in planning and timing of my } \\
\text { decisions }\end{array}$ & & &, 523 & & \\
\hline Economic downturn & & & & ,753 & \\
\hline Not having enough money to pay creditors & & & & ,745 & \\
\hline Myself or someone in my family dying & & & &, 575 & \\
\hline Not having enough resource support & & & &, 511 & \\
\hline Tax audit & & & & &, 783 \\
\hline Legal issues (being sued) & & & & & ,626 \\
\hline
\end{tabular}

Table 2: Factor Loadings of the dependendent variables: Business Performance Scale Dimensions

\begin{tabular}{|l|c|l|}
\hline KMO: ,779 & Financial Performance & Inovative Performance \\
Explained total variance: \%61,755 & $\mathbf{( \% \text { var. 13,674) }}$ & (\% var. 5,538) \\
\hline Net Profit earned from base activities &, 873 & \\
\hline Average profit &, 863 & \\
\hline Average increase of the sales &, 818 & \\
\hline Overall success level &, 742 & \\
\hline Market share &, 716 & \\
\hline The number of new product/service supply & & \\
\hline The number of successful new product /service supply & & \\
\hline
\end{tabular}




\section{Correlation Analysis}

We calculated means and standard deviations for each variable and a correlation analysis is conducted to investigate the relationship between independent variables (fear of work / social stress, fear of unknown, fear of non-monetary support, fear of uncertainty, fear of legal issues) and dependent variables (financial performance and innovative performance). According to correlation analysis from independent variables only fear of legal issues factor is correlated with performance dimensions. For financial performance $\mathrm{r}=-, 186^{* *}$; for innovative performance $\mathrm{r}=-, 229^{* *}$; the relationship between performance and fear of legal issues as expected negative but slightly small relationship between the variables. The other dimensions for fear of entrepreneur' are mostly correlate with each other. According to mean scores, work and social stress factor of fear $(3,9027)$ are the highest score, so we can say that entrepreneurs mostly fear of this dimension. Apart from fear of legal issues factor $(2,7421)$, all scores are above 3 and they generally have such fears that are mentioned in the scale.

In order to investigate the reliability scores of the factors, the cronbach alpha scale is used. Alpha values are for three dimensions above 0.70 but other 4 dimensions alpha scores are between 642 and 683 early studies support such a value as an acceptable value (i.e. Gliner, Morgan, 2000, p.313). Regarding to the results of the above statistical tests for reliability and validity, it is assumed that the factors of the variables are sufficiently valid and reliable to test hypothesis.

Table 3: Mean, Standard Deviation and Correlation Coefficients

\begin{tabular}{|c|c|c|c|c|c|c|c|c|c|}
\hline & S.D & MEAN & 1 & 2 & 3 & 4 & 5 & 6 & 7 \\
\hline 1.FP & 80582 & 3,0400 & (875) & & & & & & \\
\hline 2.IP & 1,04562 & 3,0882 &, $541(* *)$ & $(\mathbf{8 6 2})$ & & & & & \\
\hline 3.FWS & 89037 & 3,9027 &,- 009 &, 530 & $(, 749)$ & & & & \\
\hline 4.FU & 1,17560 & 3,4392 &,- 027 &,- 021 &, $285(* *)$ & (,683) & & & \\
\hline 5.FNS & ,89591 & 3,0405 &,- 069 &, 100 &, $387(* *)$ &, $343(* *)$ & $(, 642)$ & & \\
\hline 6.FUC &, 87305 & 3,4920 &,- 101 &,- 045 & ,321(**) &, $316(* *)$ &, $367(* *)$ & $(, 647)$ & \\
\hline 7.FL & 1,21131 & 2,7421 &,$- 186(* *)$ &,$- 229(* *)$ &, 114 &, $274(* *)$ & ,119 &, $253(* *)$ & $(, 645)$ \\
\hline
\end{tabular}

** Correlation is significant at the 0.01 level

$\mathrm{SD}=$ Standard Deviation ()$=$ Cronbach's alpha

FP: Financial Performance, IP: Innovative Performance, FWS: Fear of Work / Social Stress, FU: Fear of Unknown, FNS: Fear of Non-monetary Support, FUC: Fear of Uncertainty, FL: Fear of Legal Issues

\section{Regression Analysis:}

The developer of the fear of entrepreneur scale (Collins, 2007) investigated fear of entrepreneurs empirically by performance criteria which is based on owner performance and business performance and found significant associations with the factors of fear of entrepreneurs. However, in his study performance and performance criteria are examined in different performance dimensions and when comparing to factors of fear of entrepreneurs, results indicates that no specific factor of is more effective on performance.

In this study acording to linear regression findings, fear of legal issues factor is negatively associated with financial performance (beta value is $-0,194, p=0.007$ ). Beside financial performance, innovative performance and fear of legal issues are in association with each other as well (beta value is $-0,250$, $\mathrm{p}=0.00$ ). As far as we reached except Collins financial performance and innovative performance and fear of entrepreneurs has not yet studied in literature, therefore there is not another such an empirical support for comparing the findings. For other dimensions of fear of entrepreneurs and performance dimensions due to regression results statistically insignificant results were found (in the following sub -hypothesis indicates the related findings in detail). 
In the regression table Durbin Watson scores show that there is not auto-correlation between variables. Adjusted $\mathrm{R}^{2}$ score is slightly low, and indicates for financial performance that the model explains $0,037 \%$ of the sample and for innovative performance the score is $0.054 \%$.

After all we can say that our main hypothesis " $\mathrm{H} 1$ : There is relationship between entrepreneur's level of perceived business-related fear and business performance" is accepted.

\section{Table 4: Regression Analysis Results}

\begin{tabular}{|c|c|c|c|c|}
\hline \multirow{3}{*}{\begin{tabular}{|l} 
Independent Variables \\
Fear of Work / Social Stress \\
\end{tabular}} & \multicolumn{4}{|c|}{ Dependent Variables } \\
\hline & \multicolumn{2}{|c|}{ Financial Performance } & \multicolumn{2}{|c|}{ Innovative Performance } \\
\hline &,- 006 & \multirow{5}{*}{$\begin{array}{l}\mathrm{F}: 2,642 \\
\mathrm{R}^{2}:, 037 \\
\mathrm{DW}: 1,616\end{array}$} & ,046 & \multirow{5}{*}{$\begin{array}{l}F: 3,486 \\
R^{2}: 054 \\
D W: 1,834\end{array}$} \\
\hline Fear of Unknown &, 031 & & ,016 & \\
\hline $\begin{array}{c}\text { Fear of Non-monetary } \\
\text { Support }\end{array}$ &, 127 & &, 124 & \\
\hline Fear of Uncertanity &,- 114 & &,- 054 & \\
\hline Fear of Legal Issues &,$- 194 *$ & &,$- 250 * *$ & \\
\hline
\end{tabular}

Table columns contain standardized beta coefficients. "bold" values are significant. $\left(* * p<0.01,{ }^{*} p<0.05\right)$ DW: Durbin Watson value

Findings are shown in the figure 2 in detail. The hypothesis can be rewritten in the light of dimensions of the variables which has obtained by factor analysis. The sub-hypothesis and findings are summarized in the following as well.

$\mathrm{H}_{1 \mathrm{a}}$ : There is relationship between entrepreneur's level of perceived fear of work / social stress and financial performance is not supported by the regression analysis.

$\mathrm{H}_{1 \mathrm{~b}}$ : There is relationship between entrepreneur's level of perceived fear of work / social stress and innovation performance is not supported by the regression analysis.

$\mathrm{H}_{1 \mathrm{c}}$ : There is relationship between entrepreneur's level of perceived fear of unknown and financial performance is not supported by the regression analysis.

$\mathrm{H}_{1 \mathrm{~d}}$ : There is relationship between entrepreneur's level of perceived fear of unknown and innovation performance is not supported by the regression analysis.

$\mathrm{H}_{1 \mathrm{e}}$ : There is relationship between entrepreneur's level of perceived fear of non-monetary support and financial performance is not supported by the regression analysis.

$\mathrm{H}_{1 \mathrm{f}}$ : There is relationship between entrepreneur's level of perceived fear of non-monetary support and innovation performance is not supported by the regression analysis.

$\mathrm{H}_{1 \mathrm{~g}}$ : There is relationship between entrepreneur's level of perceived fear of uncertanity and financial performance is not supported by the regression analysis.

$\mathrm{H}_{1 \mathrm{~h}}$ : There is relationship between entrepreneur's level of perceived fear of uncertanity and innovation performance is not supported by the regression analysis.

$\mathrm{H}_{1 \mathrm{i}}$ : There is relationship between entrepreneur's level of perceived fear of legal issues and financial performance is supported by the regression analysis.

$\mathrm{H}_{1 j}$ : There is relationship between entrepreneur's level of perceived fear of legal issues and innovation performance is supported by the regression analysis. 
Figure 2. Final Model

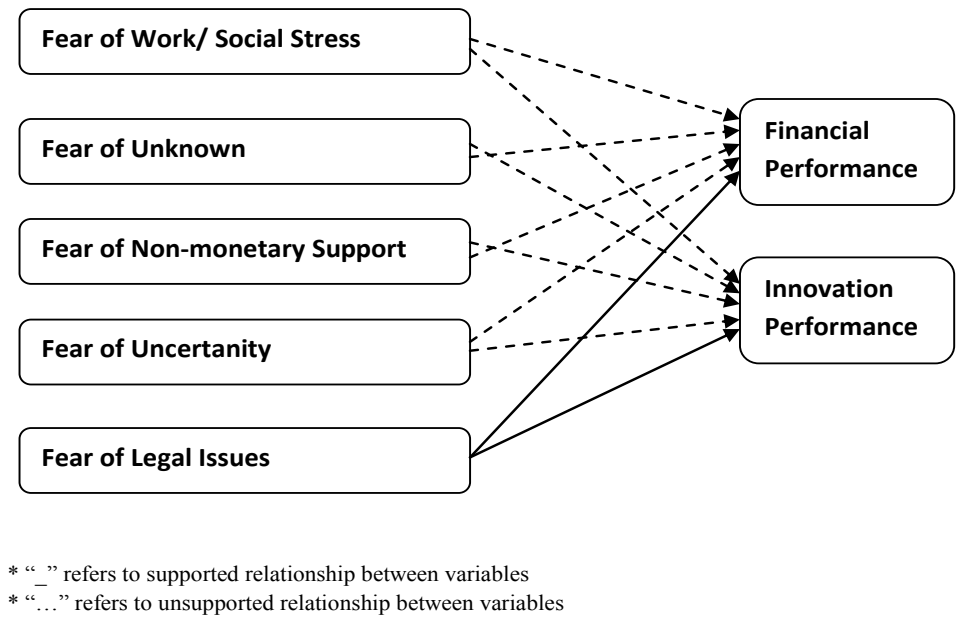

\section{CONCLUSION}

This research study has aimed to find a link between entrepreneurial fear and business performance. Fear factors affect on performance has been empirically studied in psychology literature for a long time and in workplace literature fear factor's effect on employee' attitudes has been studied accordingly. But although it is suggested by the numerous researchers, there is very little empirical research about the entrepreneurial fear factors which is the motivator point for us. Beside this, the results of the study imply that there could be a link between one of fear factors 'fear of legal issues' and both financial and innovative performance. For other dimensions results were insignificant for our sample. As it is stated in GEM global report (2009) institutional environment has strong influence on entrepreneurial activities, and our study supports the findings. In addition to these the report indicates that although there are governmental obstacles entrepreneurs in Turkey are less fearful comparing to other countries.

Specific success factors and entrepreneurial personal factors that are mentioned in the related literature are asked to the participants. We found that in our sample enterprise owners are satisfied with their performance; most of them are experienced and relatively high amount of them are born global firms which is a predictor of success according to related literature. As another significant finding; entrepreneurs' fathers are parallel to literature mostly an entrepreneur in this sample. And the most motivator factor for entrepreneurs 'want to be employer' as parallel to other researchers findings. Numerous questions are asked beside these and the relationship between fear factors and demographic variables are investigated but no significant relationship found.

\section{LIMITATIONS AND IMPLICATIONS}

Sample was unwilling to answer such private questions; because of their position and data gathering method (face-to-face). Both performance and fear are based on perception; this may be a limitation for defining the objective results. Because the dimensions of fear except 'fear of legal issues' are insignificant, the researchers should continue to test the validity of the questionnaire with different samples and the suggested relationship should be supported empirically with different cultures. May be different scales can be developed. Beside firm performance, different outputs such as creativity, well-being and organizational climate can be investigated in relation with fear of entrepreneurs.

Business owners should become more aware of and willing to seek help from coaches, mentors, and consultants in order to cope with their fears about business. Business educators should give attention to fear management interventions in their education programs so that entrepreneurs can have enough knowledge about the subject. And lastly enterprise owner should be supported by government because the negative outputs indirectly affect the whole economic system. 


\section{REFERENCES}

Aspelund, A. and Moen, O. (2005), Small international firms: Typology, performanceand implications, Management International Review, 45,pp. 37-57.

Baron, R. (1998), Cognitive mechanisms in entrepreneurship: why and when entrepreneurs think differently than other people, Journal of Business Venturing,13 (4), pp.275-294.

Baron, R.A. (2004), The cognitive perspective: a valuable tool for answering entrepreneurship's basic “why" questions, Journal of Business Venturing, 19, pp. 221-239

Barsade, S. Gibson, D. (2007), Why does affect matter in organizations, Academy of Management Perspectives, 21 (1), pp.36-59.

Benzing, C. Chu, H. M. and Kara, O. (2009), Entrepreneurs in Turkey: A Factor Analysis of Motivations, Success Factors and Problems, Journal of Small Business Management, 47, pp. 58-91.

Blanke, G. (2004), Speaking of success: Pressures entrepreneurs face and how they can overcome them, In E. Byron .Small Business A Special Report, Wall Street Journal (Eastern ed.), Jul 12, pp. 10.

Börü, D. (2006), Girişimcilik Egilimi Marmara Üniversitesi işletme Bölümü Ögrencileri Üzerine Bir Araştırma, istanbul: Marmara Üniversitesi, pp.733.

Bridge, S. vd. (1998), Understanding Enterprise, Entrepreneurship And Small Business, Macmillan Business, London.

Brun de Pontet, S. (2004), Business and well-being: The experience of entrepreneurs. M.A. dissertation, Concordia University, Canada.

Brundin, E. Patzelt, H. Shepherd, D. (2008), Managers' emotional displays and employees' willingness to act entrepreneurially. Journal of Business Venturing 23 (2), pp.221- 243

Buck, T. (2004), Ans balk at starting their own businesses, Financial Times, March, p. 8.

Cardon, M.Wincent, J. Singh, J. Drnovsek, M. (2009), The nature and experience of entrepreneurial passion. Academy of Management Review 34, (3).

Collins,D.D.,(2007), Entrepreneurial Success: The Effect Of Fear On Human Performance, A Dissertation Presented in Partial Fulfillment Of the Requirements for the Degree Doctor of Philosophy.

Cook, P. (2005), Formalized risk management: Vital tool for project and business success, Cost Engineering, 47 (8),pp.12-13.

Corbett, A. (2007), Learning asymmetries and the discovery of entrepreneurial opportunities. Journal of Business Venturing 22 (1), pp. 97-118.

Corbett, A. Hmieleski, K. (2007), The conflicting cognitions of corporate entrepreneurs. Entrepreneurship Theory and Practice 31 (1), pp.103-121.

Corbett, A. Hmieleski, K.(2007), The conflicting cognitions of corporate entrepreneurs, Entrepreneurship Theory and Practice 31 (1),pp. 103-121.

Coulter, M.(2001), Entrepreneurship in Action, Prentice Hall Inc, New Jersey.

Doctor, M. and Kahn P. (1989), The Encyclopaedia of Phobias, Fears, and Anxieties, Facts on File,New York.

Eren, Ş. (2006), Şirket Girişimciliğine Etki Eden Faktörler Ve Şirket Girişimciliği İle İşletme Performansı İlişkisi Üzerine Bir Saha Araştırması, Gebze Yüksek Teknoloji Enstitüsü, Sosyal Bilimler Enstitüsü, Yayınlanmamış Doktora Tezi (Supervisor Cemal Zehir).

Farmilant, S. R. (1995), Rasch analysis of the fear survey schedule-III. Psy.D. dissertation, Adler School of Professional Psychology, United States Illinois.

Farzaneh,G.Hassan,A.Gholamreza,P.Mirsalaldin,E. Parviz,A.Alireza H.(2010), Relationship Between Creativity, Grade Point Average, Achievement Motivation, Age and Entrepreneurship among University Students, Australian Journal of Basic and Applied Sciences, 4(10),pp.5372-5378. 
Forgas, J, (2000), Feeling and Thinking: Affective Influences on Social Cognition. Cambridge University Press, New York.

Gleason, K., Madura, J., Wiggenhorn, J. (2006), Operating characteristics, risk, and performance of born-global Firms, International Journal of Managerial Finance, 2,pp. 1743- 9132.

Gliner, J.A. Morgan, A.G. (2000), Research methods in applied settings: an integrated approach to design and analysis, pp.313.

Hareli, S., Shomrat, N., \& Biger, N. (2005), The role of emotions in employees' explanations for failure in the workplace. Journal of Managerial Psychology, 20(8), pp. 663-680.

Helms, M. M. (2003), Japanese managers: Their candid views on entrepreneurship, Competitiveness Review, 13(1), pp. 24.

Howorth, C., Tempest, S., Coupland, C. (2005). Rethinking entrepreneurship methodology and definitions of the entrepreneur, Journal of Small Business and Enterprise Development, 1.12 (1), pp.24-40.

Karateke, G. (2006), Kadınları Girişimciliğe İten Faktörler, Marmara Üniversitesi Sosyal Bilimler Enstitüsü (Yayınlanmamış Yüksek Lisans Tezi), İstanbul.

Knight, G. Çavuşgil, S. (2005), A taxonomy of born-global firms, Management International Review, 45,pp. 15-35.

Kutanis, R. Özen - Alpaslan, Sümeyra (2006),Girişimci ve Yönetici Kadınların Profili Farklı mıdır?, Afyon Kocatepe Üniversitesi İ̈BF Dergisi, c. VIII, sy.2, pp. 139-153.

Kutanis, R, Hancı, A.(2004), "Kadın Girişimcilerin Kişisel Özgürlük Algılamaları”, 3.Ulusal Bilgi, Ekonomi ve Yönetim Kongresi, 25-27 Mayıs, Eskişehir.

Lazarus, R. (1991), Emotion and Adaptation. Oxford University Press, New York.

Mogharabi, S. (2005), Lesson from the Donald: Here are our five favorite business lessons form Donald Trump's hit show, “the apprentice.” Pool and Spa News, June.

Naktiyok, A. (2004), İç Girişimcilik, Beta Basım Yayım, İstanbul.

Niels, K.D.Ernesto, B.JAmorós, J.E.(2010),Global Entrepreneurship Monitor (GEM), Global Report.

Oviatt, B.McDougall, P. (1994), Toward a theory of international new ventures, Journal of International Business Studies, 25,pp. 45-64

Rose, R.C.Kumar N. and Yen, L. (2006), Entrepreneurs Success Factors and Escalation of Small and Medium-sized Enterprises in Malaysia, Journal of Social Sciences 2 (3),pp. 74-80.

Roseman, I. (2001), A model of appraisal in the emotion system: integrating theory, research, and applications. In: Appraisal Processes in Emotion: Theory, Methods and Research. Oxford University Press, New York.

Runyan, R. C. (2005), Predicting downtown and small business success:A resourcebased view. Ph.D. dissertation, Michigan State University.Ryan, K. D. And Oestreich, D. K. (1998), Driving fear out of the workplace: Creating the high trust, high performance organization. Jossey-Bass Books: San Francisco.

Ryan, K. and Oestreich, D. (1991), Driving fear out of the organisation, Jossey-Bass Publishers, San Francisco.

Shahhosseini, A.Kavousy, E.Shirsavar, H.R.Ardahaey, F.(2011), Appointing the Level of Individual Entrepreneurship of Islamic Azad University Students, Asian Social Science Vol. 7, No. 1; January, pp.106-114.

Shane, S., (2003). A General Theory of Entrepreneurship: The Individual-Opportunity Nexus. Elgar, Cheltenham, UK and Northampton, Mass.

Shane, S. Venkataraman, S. (2000), The promise of entrepreneurship, Academy of Management Review 25 (1), pp.217-226.

Stern, S. (2004). Rules to stay cool in the office jungle, Financial Times, May 5, p. 12. 
Strongman, K. (1996). The psychology of emotion: Theories of emotion inperspective, 4th edn. West Sussex, England: John Wiley \& Sons \& Sons.

Tebbutt, D. (2005), European Business Forum, Autumn (22), pp.20-21.

Tuvin, E. (1995). How can we get out of the mess we've created?,The Journal for Quality and Participation,

18(2),pp. 90.

Yorton, T. (2005). Using improv methods to overcome the fear factor, Employment Relations Today, 31(4),pp. 7-13. 